\title{
Soil Copper and Zinc Accumulation and Bioavailability under a Long Term Vineyard Cultivation in South Italy
}

\author{
Paolo Lorenzoni ${ }^{1 *}$, Giuseppe Valboa ${ }^{2}$, Rossella Papini ${ }^{2}$, Raffaele Paone ${ }^{3}$, \\ Giovanni Aramini ${ }^{3}$, Caterina Colloca ${ }^{3}$, Anna Maria Corea ${ }^{3}$ \\ ${ }^{1}$ CRA - Istituto Sperimentale per lo Studio e la Difesa del Suolo - Sezione di Conservazione del Suolo, \\ Via Casette 1, 02100 Rieti, Italy \\ ${ }^{2}$ CRA - Istituto Sperimentale per lo Studio e la Difesa del Suolo - Sezione di Chimica del Suolo, \\ Piazza M. D’Azeglio 30, 50121 Firenze, Italy \\ ${ }^{3}$ Agenzia Regionale per lo Sviluppo e per i Servizi in Agricoltura (ARSSA Calabria) - \\ Servizio Agropedologia, Via Cagliari 16, 88063 Catanzaro, Italy
}

Received: 14 March 2006. Accepted: 7 July 2006

\begin{abstract}
Soil metal contamination, particularly by copper, is a phenomenon which often occurs in the surface layer of vineyard soils, due to the widespread application of $\mathrm{Cu}$-based products in the plant disease management. Our study was focused on soil $\mathrm{Cu}$ and $\mathrm{Zn}$ accumulation and bioavailability as related to some soil properties under a long term vineyard cultivation, in a D.O.C. wine area of South Italy (Calabria region). Soils selected from different landscape units, ranging from acid to alkaline, under homogeneous climate conditions and vineyard management system, were investigated. Each soil was sampled in both a vineyard and a fallow area, at the depth levels of $0-10 \mathrm{~cm}, 10-25 \mathrm{~cm}$ and $25-50 \mathrm{~cm}$. The experimental data were analysed by ANOVA, correlation and multiple stepwise regression procedures. As expected, the results indicated a contamination of the vineyard soils by $\mathrm{Cu}$ due to the repeated application of $\mathrm{Cu}$-based products in the plant disease control, with increments of total $\mathrm{Cu}$ content up to $150 \%$ against the fallow soils. On the contrary, the results led to exclude any soil $\mathrm{Zn}$ pollution due to the vineyard management and to suppose a main pedogenic origin for this metal. According to the relationships between Cu content and soil properties, $\mathrm{Cu}$ accumulation was promoted by higher $\mathrm{pH}$, clay and organic matter contents. These soil properties also showed a strong influence on metal bioavailability, which underwent a significant reduction in soils with higher $\mathrm{pH}$ and clay contents. A further result of great significance was the adverse impact of soil erosion, enhanced by the application of not suitable management systems in hilly areas, on soil capability to retain polluting metals. Soil $\mathrm{pH}$, organic matter content and texture, as well as soil management system, are key factors in soil capability to limit polluting metal dispersion in the environment.
\end{abstract}

Key-words: copper, zinc, availability index, vineyard, soil pollution.

\section{Introduction}

Heavy metals occur in small amounts in natural ecosystems (soil, water), where they can arrive by atmospheric depositions during catastrophic events (volcanic eruptions, extensive wood fires), even if their main natural source is represented by pedogenic substrata, whose metal enrichments depends on the weathering processes of rocks and their mineralogical composition.

In the last years heavy metals have become a matter of a thorough scientific research, mainly aimed to assess their dangerousness for man and environment. The potential detrimental effects of heavy metals in the soil environment arise from their not-biodegradable nature and subsequent tendency to accumulate, as well as from their toxicity towards all organisms. Their harmfulness, anyway, varies from element to element. In fact, while some metals are particularly toxic $\left(\mathrm{Cd}, \mathrm{Hg}, \mathrm{Cr}^{\mathrm{VI}}\right)$, others, on the contrary $(\mathrm{Cu}, \mathrm{Zn}, \mathrm{Mn}, \mathrm{Mo}, \mathrm{B}, \mathrm{Se})$, become toxic after exceeding a specific threshold level, whereas at low concentrations they act as essential micronutrients in several metabolic processes of higher plants and animals. Moreover, for each 
metal in soil, a chain of physical-chemical dynamic equilibria occurs among: (i) the potentially inert metal pool, temporary occluded into the crystalline lattice of primary minerals, whose release depends on the weathering degree of minerals themselves; (ii) the available pool, more or less strongly held by the chemically active soil components (clay minerals, oxides, organic matter) through adsorption, complexation and chelation mechanisms; and (iii) the metal pool dissolved in soil solution (McLean and Bledsoe, 1992). This latter pool, whose mobility depends on the metal state (free ion or bound to organic or inorganic functional groups) represents the most hazardous fraction for living organisms, being readily available for plant uptake and, therefore, easily transferable to humans and animals through the food chain. The soluble fraction, furthermore, can be redistributed along soil profile by leaching processes and moved into the groundwater, with possible contamination of drinking water supplies. According to this preliminary statement, soil heavy metal pollution is due to a disturbance of natural equilibria. Agricultural soils, in particular, are subject to metal inputs deriving from crop management, through the application of inorganic, organic and organic-mineral fertilizers, pesticides and composts obtained with a wide variety of materials (sewage sludges, urban solid wastes, food industry wastes, livestock dejections) (Moolenaar and Lexmond, 1999). In the long period, the accumulation of these elements can adversely impact soil fertility and crop product quality, as well as contaminate surface water bodies and groundwater (by soil erosion and leaching, respectively), with severe risk for human health. Therefore, the knowledge of heavy metal content in agricultural soils is of great significance, in order to protect soil quality. The several laws in force in European and non-European countries consider, as reference threshold for soil metals, their total content, extracted by strong reactants (usually aqua regia), which includes nearly the whole of metal inert fraction together with, obviously, the most reactive forms, closely related to the bioavailable pool. Dutch regulations also consider some soil properties, and in particular clay and organic matter, for their primary contribution to soil buffering capacity and their active role in mechanisms controlling metal bioavailability and/or mobility, indicating, for a good soil quality, different guide values depending on the above mentioned soil components, but also in this case in terms of soil total metal content. Italian law, through the ministerial decree N. 471 of 10/25/1999, sets the admissible concentration limits for 94 substances in soil and subsoil, nevertheless considering only two cases: 1) sites assigned to public, private and residential parks and gardens; 2) sites assigned to commercial and industrial activities. Therefore, the decree does not define the concentration limits for agricultural soils, entrusting the Ministry of Agricultural and Forestal Policies with this task. According to the law, copper and zinc concentration limits are, respectively, 120 and $150 \mathrm{mg} \mathrm{kg}^{-1}$ in the first case, and 600 and $1500 \mathrm{mg} \mathrm{kg}^{-1}$ in the second case (Gazzetta Ufficiale della Repubblica Italiana, 1999).

Many researchers have tested a number of different extraction procedures to evaluate the potentially mobile and/or bioavailable metal fraction in soil and, thus, obtain a measurement suitable to represent the effective risk for ecosystems better than total metal content (Lebourg et al., 1996).

Our study was focused on soil contamination by $\mathrm{Cu}$ and $\mathrm{Zn}$ as a result of long term vineyard cultivation, in an agricultural area of Calabria Region, in South Italy. Use of copper products as fungicide against downy mildew is still widely spread in vineyard cultivations, both under conventional and biological management, but information about copper enrichment of soils is quite lacking. In particular, the investigation concerned the total and the bioavailable contents of the above mentioned metals and their possible relations with some soil properties, in order to evaluate soil capability to accumulate these contaminants and to prevent or slow down their migration in the various environment compartments. Such knowledge is an essential starting point to evaluate, in a further step of our research, the development of a potential risk situation by the definition of a metal balance, as carried out by other Authors for vineyard agroecosystems (Moolenaar and Beltrami, 1998).

\section{Materials and methods}

The investigation was carried out within the area of Cirò D.O.C. wine, located at the northern side of the province of Crotone (Calabria, 


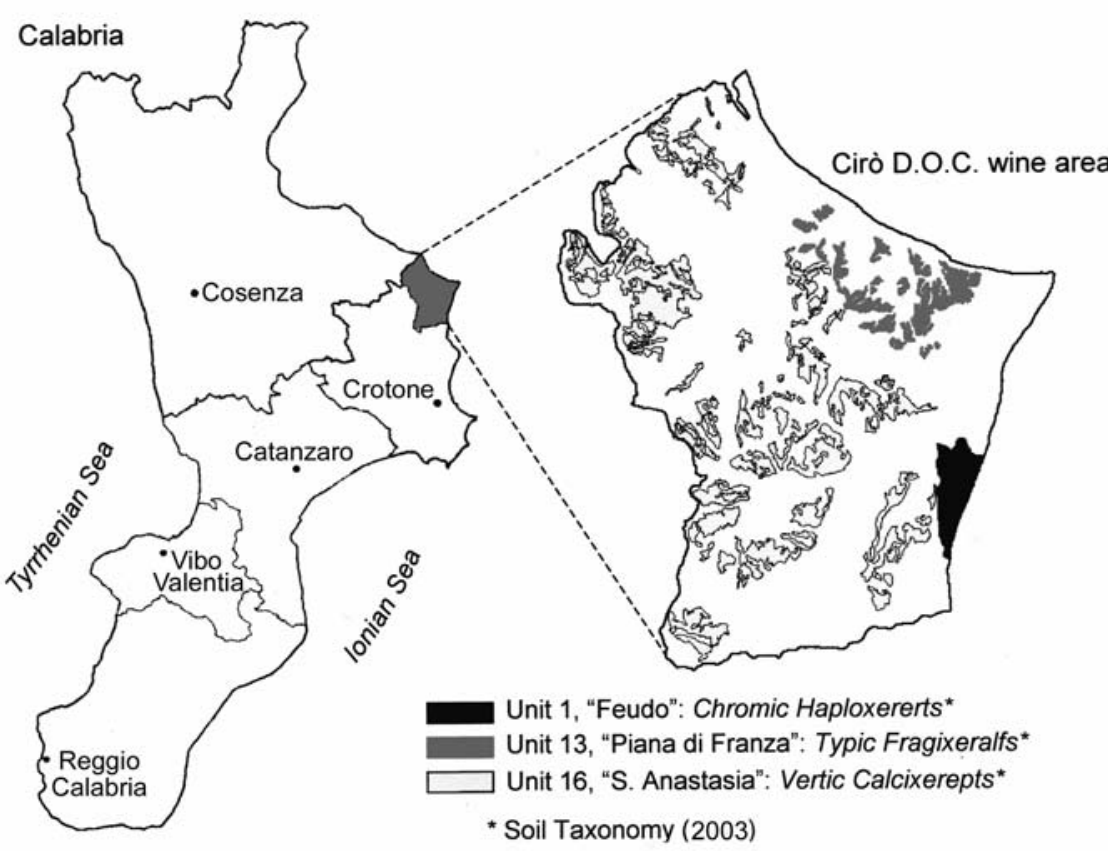

Figure 1. Soil distribution for the selected cartographic units within Cirò DOC wine area (northern side of the province of Crotone, Calabria region, South Italy).
South Italy) (Figure 1). The knowledge of soil nature and distribution in the considered area was possible thanks to a previous pedological study for wine zonation carried on by the Regional Agency for Agriculture Development and Services (ARSSA Calabria, 2002). Soils under examination belong to three different cartographic units $(\mathrm{CU})$, in which vineyard is the main land use: CU 1 (Feudo), CU 13 (Piana di Franza) and CU 16 (S. Anastasia). The CU 1 in size 334 ha is and is represented by a holocene marine terrace with nearly-level morphology, placed at an altitude between 8 and $14 \mathrm{~m}$ a.s.l. and made up of fine sediments eroded from the marly hills standing behind. Soils are Chromic Haploxererts according to Soil Taxonomy (Hapli-Calcic Vertisols in accordance with World Reference Base). The CU 13 extends up to 528 ha and consists of nearly-level residual strips of an ancient terraced surface, placed at an altitude between 50 and $100 \mathrm{~m}$ a.s.l. and made up of pleistocene non-calcareous coarse sediments. Soils are classified as Typic Fragixeralfs (S.T.) or Chromi-Gleyic Luvisols (WRB). CU 16, covering a $3281 \mathrm{ha}$, is represented by hill slopes with complex morphology and incline usually ranging below $20 \%$, mainly exposed to south and placed between 50 and $200 \mathrm{~m}$ a.s.l. Soils belonging to this unit were developed on miocenic marly clays and are classified as Vertic Calcix- erepts according to S.T. (Hypocalci-Vertic Calcisols in accordance with WRB).

The investigated areas are homogeneous for what concerns climate and vineyard farming system. According to the climatic data recorded in the thirty-year period $1957-1987$ by the reference thermopluviometric station located in Cirò Marina (6 $\mathrm{m}$ a.s.l.), the rainfall averages $748 \mathrm{~mm}$ year $^{-1}$, with monthly values ranging from $8.2 \mathrm{~mm}$ in July to $131 \mathrm{~mm}$ in October. Temperature has an annual average of $15.8^{\circ} \mathrm{C}$, with a maximum monthly of $23.1^{\circ} \mathrm{C}$ in July (ARSSA Calabria, 2002).

The vineyard management is of conventional type, with tree line orientation along the maximum gradient on hilly soils and absence of grass in the line space. The plant phytosanitary treatments include four copper oxychloride applications per year, with an average total copper application of $12 \mathrm{~kg} \mathrm{ha}^{-1}$. Soils tillage consists of five harrowings per year.

A layered random sampling, with $1 \mathrm{~km}$ grid square cells, was performed for the selected soils. Each soil was sampled in nine locations and at three depths: $0-10 \mathrm{~cm}, 10-25 \mathrm{~cm}$ and 25 $50 \mathrm{~cm}$. The first two levels are representative of the top soil, while the deepest one represents the soil layer not interested by tillage. A similar sampling procedure was executed in fallow areas of the CU 13 and 16 (no fallow area was 
available for the $\mathrm{CU} 1$ in the considered environment), in order to obtain information about soil $\mathrm{Cu}$ and $\mathrm{Zn}$ background values. The sampling points were four in each fallow area. Soil samples were air dried and sieved through a $2 \mathrm{~mm}$ mesh. Laboratory analysis were performed according to the Italian standard procedures of soil chemical analysis (MiPAF, 2000). In particular, soil texture was determined after dispersion in sodium hexametaphosphate, using the pipette method for clay and silt fractions, and wet sieving to separate sand fraction. The measured values of sand, silt and clay were introduced in the calculation of the texture index (TI), as referred by Sillanpää (1990), on the basis of the formula: $\mathrm{TI}=1.0(\%$ Clay $)+0.3(\%$ Silt) +0.1 (\% Sand). Soil pH was measured by a $\mathrm{pH}$-meter using a 1:2.5 (w/v) soil/water ratio. Organic carbon content (OC) was determined by the Walkley-Black method. Total carbonate and active $\mathrm{CaCO}_{3}$ contents were respectively analysed by Dietrich-Fruehling calcimeter and Drouineau method. Cation exchange capacity (CEC) analysis was carried out by ammonium acetate ( $\mathrm{pH} \mathrm{7)}$ for the acid soil (CU 13) and barium chloride-triethanolamine $(\mathrm{pH}$ 8.2) for the alkaline soils (CU 1 and CU 16). Copper and zinc analysis concerned both the total content and the available fraction. The total content was extracted in a 3:1 'aqua regia' ( $\mathrm{HCl}: \mathrm{HNO}_{3}$ mixture), by digestion in a microwave oven. The available content was extracted using the Lindsay and Norwell method for the alkaline soils (DTPA $0.005 \mathrm{M}, \mathrm{CaCl}_{2} 0.01$ $\mathrm{M}$ and triethanolamine $0.1 \mathrm{M}$, at $\mathrm{pH} 7.3$ ), and the Lakanen and Erviö method for the acid soil (EDTA/Ammonium Acetate, at pH 4.65). Metal concentrations in soil extracts were determined by flame atomic absorption spectrometry (AAS). The total/available metal percentage ratio was used to evaluate the metal availability index (AI).

The differences between the compared soils were evaluated on the basis of one way ANOVA procedures for each depth level. In order to investigate the relationships between soil properties and the considered metals, the whole dataset of the vineyard soils was processed through correlation and stepwise multiple regression analysis.

The "**" symbol accompanying the correlation and determination coefficients indicates the statistical significance (* significant at $P<0.05$; ** significant at $P<0.01$; *** significant at $P<$ 0.001). All the mentioned analysis were performed using the SPSS statistical software package, version 6.1.

\section{Results and discussion}

\subsection{Soil properties}

Table 1 shows the mean values for some soil properties measured at the different sampling depths. The main factors discriminating the compared soils are $\mathrm{pH}(<6$ for $\mathrm{CU} 13,>8$ for CU 1 and 16), texture, organic carbon content and CEC. In particular, data show for the CU 13 soil OC contents significantly lower and a texture largely richer in sand than for soils of the other units. In accordance with these differences, the CU 13 soil also exhibits the lowest CEC values. Soil $\mathrm{pH}$ does not vary between the two alkaline units, despite the lower carbonate content in the $\mathrm{CU} 1$. The soils of this unit, besides, differs from those of CU 16 for a finer particle size and a higher OC content, whose accumulation is quite likely enhanced by a lower susceptibility to erosion (terraced surface for CU 1, hill slope for CU 16). Consequently, also CEC is higher for CU 1 soil than for CU 16 soil. The multiple regression analysis, performed on the whole dataset, confirms for CEC a close relation with soil mineral and organic constituents, on the basis of the equation:

$$
\begin{gathered}
\mathrm{CEC}=9.786+0.360 \mathrm{OC}+0.258 \text { Clay } ; \\
\mathrm{R}_{\mathrm{m}}^{2}=0.323^{* * *}
\end{gathered}
$$

\subsection{Copper}

As shown in figure 2. $\mathrm{A}, \mathrm{Cu}$ accumulation in the vineyard soils mainly concerns the first centimeters of depth, where its total content ranges from comparable values in CU 13 and 16 soils (approximately $37 \mathrm{mg} \mathrm{kg}^{-1}$ ), to about 1.7 times higher values in CU 1 soil $\left(64 \mathrm{mg} \mathrm{kg}^{-1}\right)$. Their decrements as a function of depth, measured as percentage difference between the contents at $0-10 \mathrm{~cm}$ and at $25-50 \mathrm{~cm}$, are of $30-40 \%$ for unit 1 and 16 soils, and of $57 \%$ for unit 13 soil. Such distribution along soil profile is typical of soils subject to $\mathrm{Cu}$ depositions at surface, where the metal tends to persist due to its capacity to bind to organic matter, $\mathrm{Al}$ and $\mathrm{Fe}$ oxides and clay minerals (Adriano, 1986), and thanks to its ap- 
Table 1. Soil properties at the different sampling depths (mean values).

\begin{tabular}{|c|c|c|c|c|c|c|c|c|c|c|c|c|c|c|}
\hline \multirow{3}{*}{ Soil } & \multirow{3}{*}{$\begin{array}{c}\text { Depth } \\
(\mathrm{cm})\end{array}$} & \multirow{3}{*}{$\mathrm{pH}$} & \multicolumn{2}{|c|}{$\mathrm{CaCO}_{3}$} & \multirow{3}{*}{$\begin{array}{c}\mathrm{OC} \\
\left(\mathrm{g} \mathrm{kg}^{-1}\right)\end{array}$} & \multicolumn{7}{|c|}{ Particle size $\left(\mathrm{g} \mathrm{kg}^{-1}\right)$} & \multirow{3}{*}{ Clay } & \multirow{3}{*}{$\begin{array}{c}\mathrm{CEC} \\
\left(\mathrm{cmol}_{[+]} \mathrm{kg}^{-1}\right)\end{array}$} \\
\hline & & & tot. & act. & & \multicolumn{4}{|c|}{ Sand } & \multicolumn{3}{|c|}{ Silt } & & \\
\hline & & & \multicolumn{2}{|c|}{$\left(\mathrm{g} \mathrm{kg}^{-1}\right)$} & & c.m. & $f$. & $v . f$. & tot. & $c$ & $f$ & tot. & & \\
\hline CU 1 & $0-10$ & 8.2 & 172.4 & 67.6 & 11.9 & 11 & 29 & 98 & 139 & 133 & 395 & 540 & 322 & 22.2 \\
\hline CU 16 & “ & 8.1 & 222.8 & 77.9 & 9.0 & 26 & 48 & 149 & 224 & 147 & 340 & 487 & 289 & 20.5 \\
\hline CU 13 & “ & 5.9 & 0.0 & 0.0 & 7.8 & 183 & 149 & 131 & 465 & 113 & 206 & 319 & 216 & 16.7 \\
\hline CU 1 & $10-25$ & 8.1 & 172.3 & 77.7 & 10.2 & 11 & 30 & 99 & 140 & 121 & 417 & 538 & 322 & 20.3 \\
\hline CU 16 & “ & 8.1 & 218.8 & 82.0 & 7.3 & 24 & 47 & 147 & 218 & 150 & 338 & 488 & 293 & 20.4 \\
\hline CU 13 & “ & 5.8 & 0.0 & 0.0 & 5.2 & 179 & 125 & 131 & 436 & 117 & 211 & 328 & 236 & 17.7 \\
\hline CU 1 & $25-50$ & 8.2 & 177.3 & 70.5 & 9.0 & 11 & 34 & 94 & 138 & 144 & 389 & 533 & 329 & 23.1 \\
\hline CU 16 & “ & 8.2 & 232.9 & 80.3 & 5.7 & 22 & 40 & 125 & 187 & 146 & 361 & 507 & 306 & 21.1 \\
\hline CU 13 & “ & 5.9 & 0.0 & 0.0 & 3.8 & 176 & 121 & 129 & 425 & 120 & 226 & 346 & 228 & 16.7 \\
\hline
\end{tabular}

sand: $c . m .=$ coarse and medium $(2-0.25 \mathrm{~mm}) ; f .=$ fine $(0.25-0.1 \mathrm{~mm}) ; v \cdot f .=$ very fine $(0.1-0.05 \mathrm{~mm})$ silt: $c$. $=$ coarse $(0.05-0.02 \mathrm{~mm}) ; f .=$ fine $(0.02-0.002 \mathrm{~mm})$

titude, in alkaline soils, to form chemical species characterized by reduced solubility and mobility (hydroxides, carbonates, hydroxi-carbonates) (Cavallaro and McBride, 1980). In the fallow soils and under the same environmental conditions, $\mathrm{Cu}$ content is significantly lower (Fig. 3A) and uniformly distributed with depth, which indicate, in this case, a main lithogenic nature of

Total Cu (mg kg $\left.{ }^{-1}\right)$

Available Cu (mg kg $\left.{ }^{-1}\right)$

Cu-AI (\%)

$\begin{array}{lllllllll}0 & 10 & 20 & 30 & 40 & 50 & 60 & 70 & 80\end{array}$
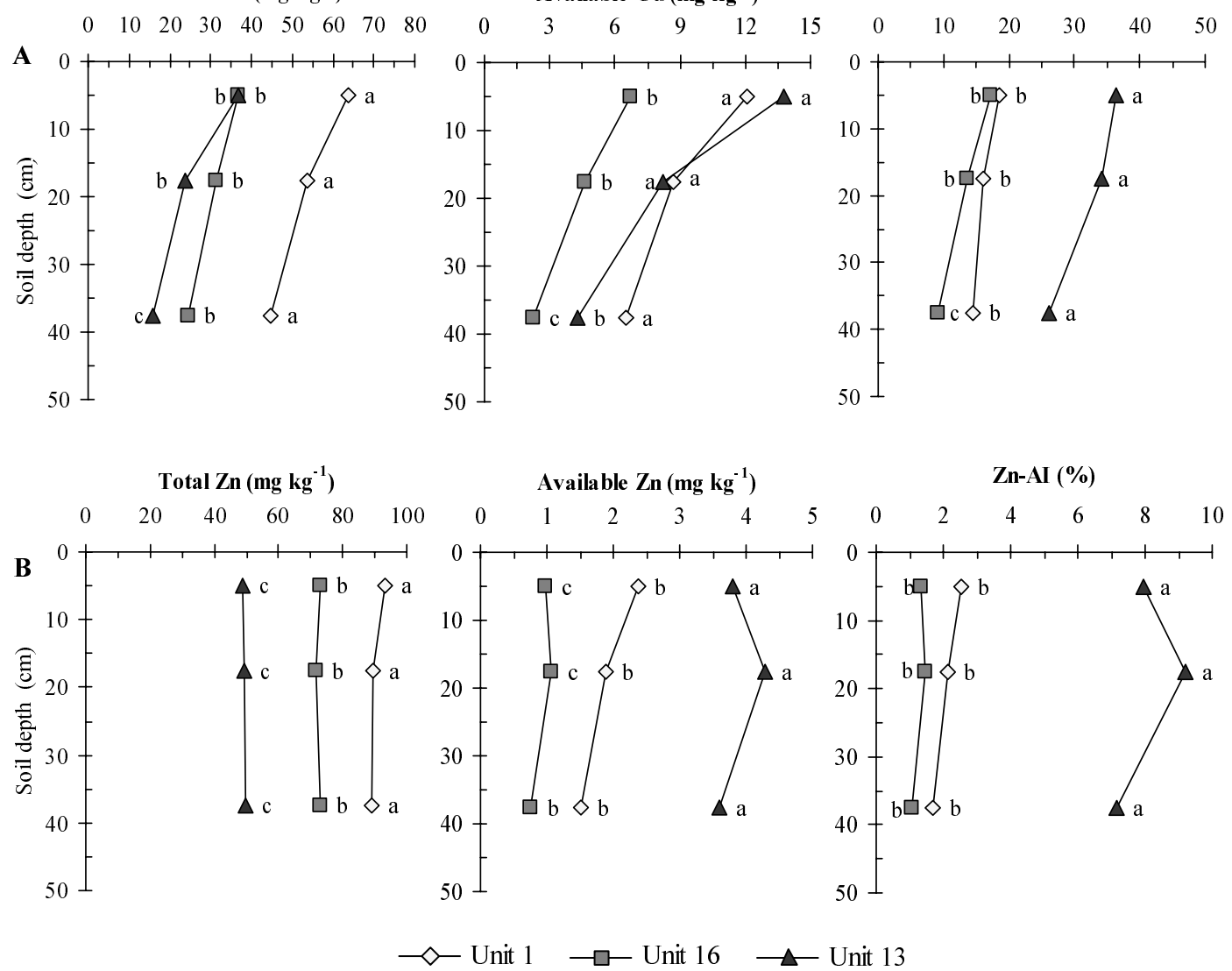

Figure 2. $\mathrm{Cu}$ and $\mathrm{Zn}$ contents and availability indexes (AI) as a function of soil depth in the vineyard soils. Mean values accompanied by equal letters indicate, at each depth, differences statistically not significant at the probability level $P=0.05$. 
A

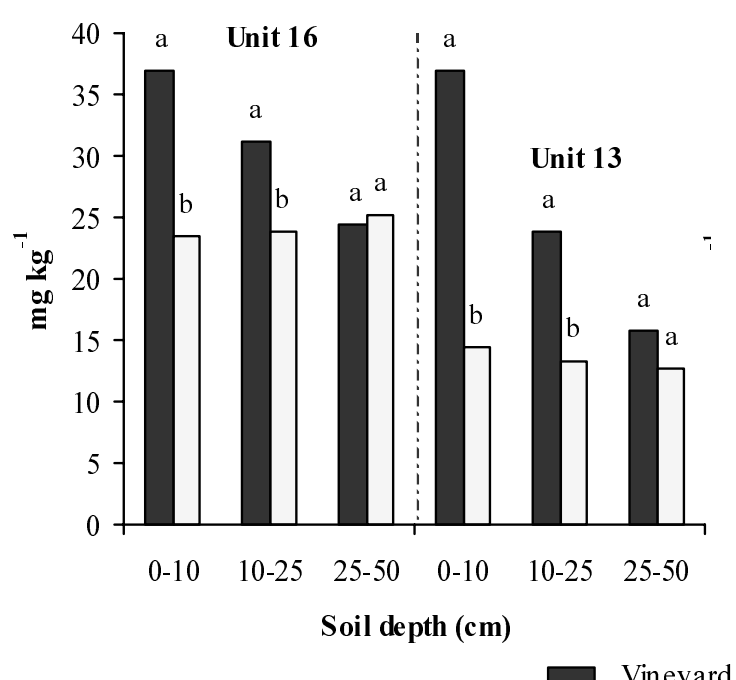

B

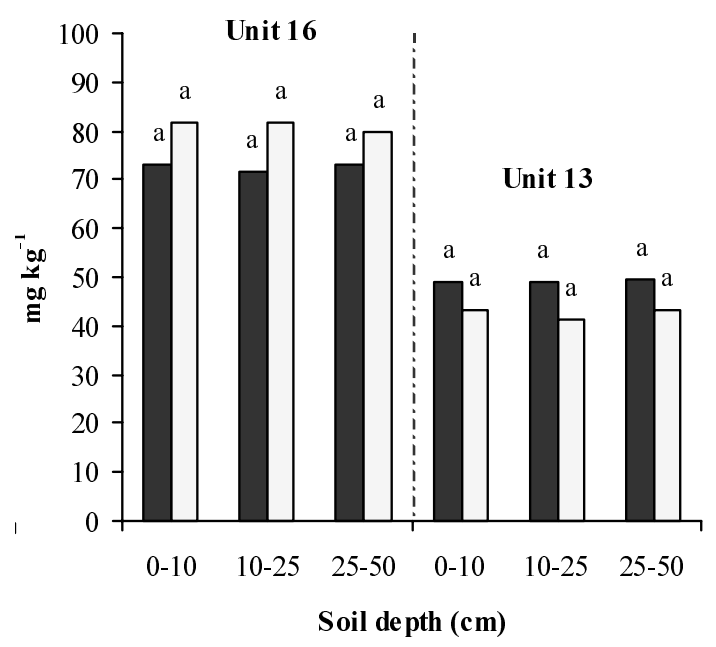

Fallow

Figure 3. $\mathrm{Cu}$ and $\mathrm{Zn}$ total contents at the different sampling depths in the vineyards and in the respective fallow soils of the units 13 and 16. Mean values accompanied by equal letters indicate, at each depth, differences statistically not significant at the probability level $P=0.05$.

metal. In particular, it averages $24.2 \mathrm{mg} \mathrm{kg}^{-1}$ and $13.5 \mathrm{mg} \mathrm{kg}^{-1}$ in the fallow soils of the units 16 and 13, respectively. These values, obviously, depend on both $\mathrm{Cu}$ amount deriving from the weathering of pedogenic substratum, and those factors controlling metal dynamics under the specific conditions of the considered soils. On the basis of the results of the correlation analysis (Tab. 2), $\mathrm{Cu}$ accumulation is promoted by higher contents of organic matter and clay, and by higher $\mathrm{pH}$ values. The multiple regression analysis indicates the following relation as the best combination of factors related to the total $\mathrm{Cu}$ content:

$$
\begin{gathered}
\text { Total } \mathrm{Cu}=-6.022+4.047 \mathrm{OC}+ \\
0.404 \text { Clay; } \mathrm{R}_{\mathrm{m}}^{2}=0.633 * * *
\end{gathered}
$$

Organic matter is among the most active soil components in $\mathrm{Cu}$ adsorption and fixation processes (Adriano, 1986). McLaren et al. (1981) indicate for soil constituents a capacity to fix $\mathrm{Cu}$ decreasing as follows:

$$
\begin{aligned}
& \text { Mn oxides }>\text { organic matter }>\text { Fe oxides }> \\
& \text { clay minerals }
\end{aligned}
$$

Nevertheless, in soils with modest amounts of organic matter, clay mineral fraction and $\mathrm{Fe}$ oxides may dominate the mechanisms of $\mathrm{Cu}$ adsorption (McLaren and Crawford, 1973). Stevenson and Fitch argue that, due to the strong aptitude of clay and organic matter to bind together, it is possible that both these soil components are involved in $\mathrm{Cu}$ retention, through the formation of clay-Cu-organic matter complexes (Stevenson and Fitch, 1981). Therefore, the CU 13 soil, compared to the oth-

\begin{tabular}{|c|c|c|c|c|c|c|c|c|}
\hline & $\mathrm{pH}$ & tot $\mathrm{CaCO}_{3}$ & $\mathrm{OC}$ & $\mathrm{CEC}$ & Sand & Silt & Clay & $\mathrm{TI}$ \\
\hline Total $\mathrm{Cu}$ & $0.473^{* * *} *$ & $0.335 * *$ & $0.780 * * *$ & $0.318^{* *}$ & $-0.532 * * *$ & $0.505^{* * *} *$ & $0.430 * * *$ & $0.487 * * *$ \\
\hline Available $\mathrm{Cu}$ & -0.207 & $-0.295 * *$ & $0.511 * * *$ & -0.018 & 0.113 & -0.143 & -0.040 & -0.071 \\
\hline $\mathrm{Cu}-\mathrm{AI}$ & $-0.810 * * *$ & $-0.821 * * *$ & -0.128 & $-0.416 * * *$ & $0.711 * * *$ & $-0.732 * * *$ & $-0.496 * * *$ & $-0.600 * * *$ \\
\hline Total $\mathrm{Zn}$ & $0.797 * * *$ & $0.708 * * *$ & $0.655 * * *$ & $0.562 * * *$ & $-0.921 * * *$ & $0.878 * * *$ & $0.742 * * *$ & $0.842 * * *$ \\
\hline Available Zn & $-0.673 * * *$ & $-0.728 * * *$ & -0.121 & $-0.308^{*}$ & $0.532 * * *$ & $-0.507 * * *$ & $-0.429 * * *$ & $-0.487 * * *$ \\
\hline $\mathrm{Zn}-\mathrm{AI}$ & $-0.783 * * *$ & $-0.801 * * *$ & $-0.310 * *$ & $-0.457 * * *$ & $0.704 * * *$ & $-0.672 * * *$ & $-0.567 * * *$ & $-0.643 * * *$ \\
\hline
\end{tabular}
er soils, naturally tends to equilibrium conditions characterized by lower amounts of total

Table 2. Correlation coefficients between some soil properties and metal contents. 
$\mathrm{Cu}$, due to its acid $\mathrm{pH}$ and lower contents of organic matter and clay. Nevertheless it is interesting to note how the units 13 and 16 soils, which in the fallow areas have significantly different contents of total $\mathrm{Cu}$, in the vineyard areas tend to accumulate similar $\mathrm{Cu}$ amounts, under homogeneous management conditions and with the same annual application of $\mathrm{Cu}$ through the fungicidal treatments. In fact, total $\mathrm{Cu}$ increments attributable to the farming activity are, on average, of $150 \%$ for CU 13 soil and of $57 \%$ for CU 16 soil. Besides, this only occurs within the surface layer, while at lower depths, as shown in Figure $3 \mathrm{~A}, \mathrm{Cu}$ content in the two vineyard soils tends to reflect that of the respective fallow soils. A possible explanation of this apparent incongruence is that, due to morphological characteristics, in the CU 16 soil the surface accumulation of copper resulting from the vineyard treatments is, in part, limited by a topsoil depletion caused by erosion processes. The natural higher susceptibility to erosion of the CU 16 soil is further enhanced by the vineyard management system (tree line orientation along the maximum gradient, absence of grass in the line space).

$\mathrm{Cu}$ accumulation in the studied areas is largely below the reference values $(200 \div 500$ $\mathrm{mg} \mathrm{kg}^{-1}$ ) indicated for different environments by Geoffrion (1975), Deluisa et al. (1996), FloresVelez et al. (1996). The highest value, measured in the vineyards of the CU $1\left(64 \mathrm{mg} \mathrm{kg}^{-1}\right)$, is lower than the threshold value in force in Italy for $\mathrm{Cu}$ soil content $\left(120 \mathrm{mg} \mathrm{kg}^{-1}\right)$. If we consider the quality criteria used in other European and non-European nations (De Fraja Frangipane et al., 1994), generally more restrictive than in Italy, defined with or without reference to soil use, only $\mathrm{Cu}$ total content of the unit 1 soil is, for example, greater than $36 \mathrm{mg} \mathrm{kg}^{-1}$, maximum admissible value for good quality soils in Holland, and a bit higher than $50 \mathrm{mg} \mathrm{kg}^{-1}$, threshold value for farming areas in Germany (Eikmann et al., 1993).

With regard to the $\mathrm{Cu}$ available fraction (Fig. 2A), also this exhibits decreasing levels with depth, with more marked decrements for the CU 13 soil. In the $0-10 \mathrm{~cm}$ layer its content averages between $6.7 \mathrm{mg} \mathrm{kg}^{-1}$ (in CU 16) and 12 $\div 14 \mathrm{mg} \mathrm{kg}^{-1}$ (in the CU 1 and 13 , with not significant differences between these two units). Also available $\mathrm{Cu}$ content is correlated with or- ganic carbon (Tab. 2), which indicates a possible contribution of organic matter to soil labile pool of this metal. Besides, it is related to soil texture and $\mathrm{pH}$ according to the equation:

Available $\mathrm{Cu}=8.612-1.933 \mathrm{pH}+$

$$
0.292 \text { total } \mathrm{Cu}+0.091 \text { Sand } ; \mathrm{R}_{\mathrm{m}}^{2}=0.879 * * *
$$

The relation [3], therefore, suggests that increments of soil finest mineral fraction promote $\mathrm{Cu}$ accumulation in not available forms, whereas decreases of soil $\mathrm{pH}$, by enhancing metal solubility, increase $\mathrm{Cu}$ mobility and availability. This, moreover, is well confirmed by the values of $\mathrm{Cu}$ availability index $(\mathrm{Cu}-\mathrm{AI})$, which in the acid soil is more than two times higher than in the alkaline soils (Fig. 2.A).

\subsection{Zinc}

Differently from what observed for $\mathrm{Cu}$, total $\mathrm{Zn}$ content in the vineyard soils does not show significant differences with soil depth (Figure 2.B), with mean values decreasing in the order:

\section{CU 1 (90.5 mg kg-1) > CU $16\left(72.5 \mathrm{mg} \mathrm{kg}^{-1}\right)>$ CU 13 (49.2 $\left.\mathrm{mg} \mathrm{kg}^{-1}\right)$}

Besides, its levels in the fallow areas do not significantly differ from those measured under vineyard (Fig. 3.B), leading to exclude soil $\mathrm{Zn}$ pollution due to the specific agronomic management and to suppose a main pedogenic origin for this metal. Referring to the above mentioned quality criteria, defined for soil total metal content, in all the investigated soils $\mathrm{Zn}$ content remains below the threshold values of both Dutch and German regulations (140 e $300 \mathrm{mg}$ $\mathrm{kg}^{-1}$, respectively).

The available $\mathrm{Zn}$ fraction shows only little decreases with depth (Fig. 2.B), with maximum values for the CU $13\left(3.8 \mathrm{mg} \mathrm{kg}^{-1}\right)$, minimum values for the CU $16\left(1.0 \mathrm{mg} \mathrm{kg}^{-1}\right)$ and intermediate values for the CU $1\left(2.4 \mathrm{mg} \mathrm{kg}^{-1}\right)$ (values measured at $0-10 \mathrm{~cm}$ depth). In close analogy with what found for $\mathrm{Cu}, \mathrm{Zn}$ availability index (Zn-AI) markedly discriminates the alkaline soils (CU 1 and 16), where it never exceed $3 \%$, from the acid soil (CU 13), where instead it reaches on average $8.1 \%$. The dimensional order of such values is, nevertheless, much lower than that measured for $\mathrm{Cu}$ (Fig. 2A and 2B).

In support of the homogeneity of factors controlling $\mathrm{Cu}$ and $\mathrm{Zn}$ dynamics in the investi- 
Total Cu vs. Total Zn

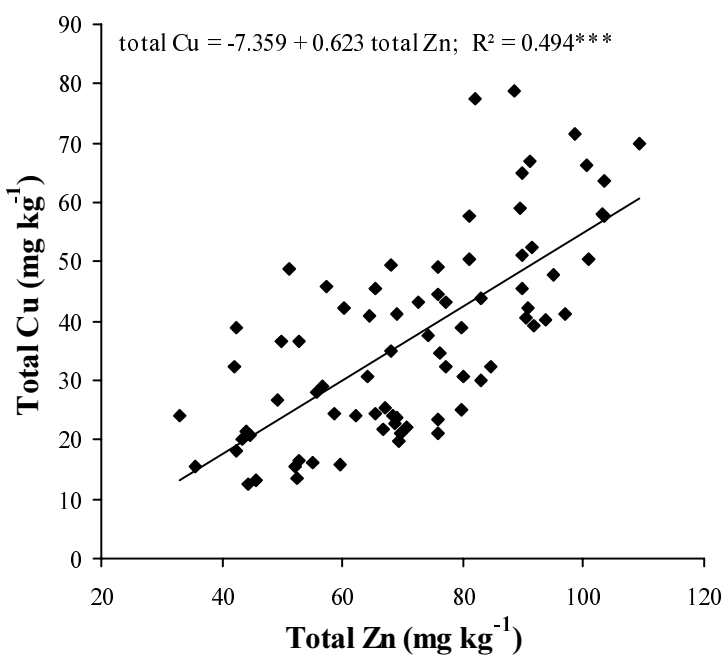

Figure 4. Relation between $\mathrm{Cu}$ and $\mathrm{Zn}$ total contents in the vineyard soils.

gated soils, their respective contents resulted intercorrelated (Fig. 4) and similarly related to soil properties. In particular, total $\mathrm{Zn}$ content was directly correlated to soil $\mathrm{pH}$, total carbonate, organic carbon, clay and CEC (Tab. 2). On the basis of the multiple regression analysis, organic carbon and coarse mineral fraction represent the group of soil variables best correlated to total $\mathrm{Zn}$, according to the equation:

$$
\begin{aligned}
\text { Total } \mathrm{Zn} & =84.827+1.553 \mathrm{OC}-0.992 \mathrm{~S} \\
\text { and } ; \mathrm{R}_{\mathrm{m}}^{2} & =0.892 * * *
\end{aligned}
$$

Available $\mathrm{Zn}$ content and $\mathrm{Zn}$ availability index $(\mathrm{Zn}-\mathrm{AI})$ were inversely related to soil $\mathrm{pH}$, total carbonates, clay and silt fractions (Tab. 2, equ. 5).

$$
\begin{aligned}
& \text { Available } \mathrm{Zn}=11.904-1.512 \mathrm{pH} \text { - } \\
& 0.094 \text { Clay }+\underset{0.561 * * *}{0.059 \text { total }} \mathrm{Zn} ; \mathrm{R}_{\mathrm{m}}^{2}=
\end{aligned}
$$

\section{Conclusions}

The long term application of $\mathrm{Cu}$-based products in the phytosanitary management of vineyards promoted an increase of total $\mathrm{Cu}$ content in the studied soils, which is nevertheless largely below the concentration limits allowed by Italian regulations.
This increase was localized mainly within the first centimetres of depth, due to a reduced downward movement of $\mathrm{Cu}$ caused by its interaction with soil organic and mineral components, and varied, under the same climatic conditions and agronomical techniques, in close relation with some soil properties. In particular, $\mathrm{Cu}$ accumulation was directly correlated with soil $\mathrm{pH}$ and with clay and organic carbon contents. Besides, these soil properties resulted as the most important factors in controlling $\mathrm{Cu}$ availability. In fact, for equal amounts of total $\mathrm{Cu}$, increments of soil $\mathrm{pH}$ and of the finest mineral fraction were associated with reductions of $\mathrm{Cu}$ available pool.

Moreover data, showed how soil capability to retain $\mathrm{Cu}$ and to reduce its dispersion in the environment can be strongly limited by conditions enhancing erosion processes. This was easily noticeable for the alkaline soil of the unit 16 which, as a result of the natural slope and of a management system based on tillage along the maximum gradient and absence of grass between the tree lines, underwent a progressive depletion of topsoil due to erosion. This process led this soil to accumulate $\mathrm{Cu}$ amounts below its potential capability and comparable with those measured in the unit 13 soil (characterized by acid $\mathrm{pH}$ and lower contents of clay and organic carbon).

The management of the investigated vineyards, instead, did not induce significant increases in soil $\mathrm{Zn}$ content, confirming that this metal is not used in specific treatments and that its possible content as impurity in fertilizers and pesticides is negligible. The amounts of the two metals were intercorrelated and showed similar correlations with soil properties. This is a further confirmation of the key role of $\mathrm{pH}$, texture and organic matter in determining soil capability to sustain heavy metal pollution and to limit their spreading in the environment.

\section{Acknowledgements}

The Authors thank R. Angelini (CRA - Istituto Sperimentale per lo Studio e la Difesa del Suolo, Rieti) for technical assistance in physical and chemical analysis, and A. Amato (ARSSA Calabria - Servizio Agropedologia) for helping in field activity. 


\section{References}

Adriano D.C. 1986. Trace Elements in the Terrestrial Environment. Springer Verlag, New York Inc., 297 pp.

ARSSA Calabria - Servizio Agropedologia, 2002. Carta dei suoli e zonazione viticola del Cirò DOC. Scala 1:25000. Monografia divulgativa, 229 pp.

Cavallaro N., McBride M.B. 1980. Activities of $\mathrm{Cu}^{2+}$ and $\mathrm{Cd}^{2+}$ in soil solutions as affected by $\mathrm{pH}$. Soil Sci. Soc. Am. J., 44:729-732.

De Fraja Frangipane E., Andreottola G., Tatàno F. 1994. Recenti sviluppi nel settore dei criteri di qualità dei suoli. Parte I: il criterio della concentrazione limite. Ingegneria ambientale, vol. 23, 5:246-262.

Deluisa A., Giandon P., Aichner M., Bortolami P., Bruna P., Lupetti A., Nardelli F., Stringari G. 1996. Copper pollution in Italian vineyard soils. Comm. Soil Sci. Plant Anal., 27:1537-1548.

Eikmann T., Kloke A., Eikmann S. 1993. Environmental medical and toxicological assessment of soil contamination. Contaminated Soil '93. Kluwer Academic Pubblishers, Dordrect (NL).

FAO, ISRIC, ISSS, 1998. World Reference Base For Soil Resources. World Soils Resources Report n. 84, FAO, Rome, Italy, 88 pp.

Florez-Velez L.M., Ducaroir J., Jaunet A.M., Robert M. 1996. Study of the distribution of copper in acid sandy vineyard soil by three different methods. Eur. J. Soil Sci., 47:523-532.

Gazzetta Ufficiale della Repubblica Italiana, 1999. Decreto ministeriale n. 471, 25/10/1999. Regolamento recante criteri, procedure e modalità per la messa in sicurezza, la bonifica e il ripristino ambientale dei siti inquinati, ai sensi dell'articolo 17 del decreto legislativo 5 febbraio 1997, n. 22, e successive modificazioni e integrazioni. Gazzetta Ufficiale, Serie generale n. 293 del 15/12/1999, Supplemento ordinario n. 218.

Geoffrion R. 1975. L'iteration des terres à vigne par une longue répétition des traitements à base de cuivre et de saufre. Phytoma - La Dèfense des végétaux, 267:14-16.
Lakanen E., Erviö R. 1971. A comparison of eight extractants for the determination of plant available micronutrients in soils. Acta Agr. Fehn., 123:223-232.

Lebourg A., Sterckeman T., Ciesielski H., Proix N. 1996. Intérêt de différents réactifs d'extraction chimique pour l'évaluation de la biodisponibilité des métaux en traces du sol. Agronomie, 16:201-215.

Lindsay W.L., Norvell W.A. 1978. Development of a DTPA soil test for zinc, iron, manganese and copper. Soil Sci. Soc. Amer. J., 42:421-428.

McLaren R.G., Crawford D.V. 1973. The specific asorption of copper by soils. J. Soil Sci., 24:443-452.

McLaren R.G., Swift R.S., Williams J.G. 1981. The adsorption of copper by soil materials at low equilibrium solution concentrations. J. of Soil Sci., 32:247-256.

McLean J.E., Bledsoe B.E. 1992. Behavior of metals in soils. EPA/540/S-92/018, USEPA, Washington, DC.

MiPAF, 2000. Ministero per le Politiche agricole e forestali. Osservatorio nazionale pedologico e per la qualità del suolo. Metodi di analisi chimica del suolo.

Moolenaar S.W., Beltrami P. 1998. Heavy metal balances of an Italian soil as affected by sewage sludge and Bordeaux mixture application. J. Environ. Qual., 27:828-835.

Moolenaar S.W., Lexmond T.M. 1999. Heavy metal balances, part I. General aspects of cadmium, copper, zinc and lead balance studies in agro-ecosystems. Journal of industrial ecology, vol. 2, 4:45-60.

Sillanpää M. 1990. Micronutrients and the nutrient status of soils. A global Study. FAO Soils Bull., 63, 208 pp.

Soil Survey Staff - Soil Conservation Service, U.S. Department of Agriculture, 2003. Keys to Soil Taxonomy. 9th Edition. Pocahontas Press, Inc. Blacksburg, Virginia (USA).

SPSS for Windows, v. 6.1.3, 1995. SPSS Inc., 444 N. Michigan Avenue, Chicago, IL 60611 (IL).

Stevenson F.J., Fitch A. 1981. Reaction with organic matter. In: Lonegran J.F., Robson A.D., Graham R.D. (eds.): Copper in soils and plants, 69-95. Academic Press, New York. 